University of Montana

ScholarWorks at University of Montana

7-1985

\title{
Going to Extremes: Why Do Sanderlings Migrate to the Neotropics?
}

\author{
J. P. Myers \\ Academy of Natural Sciences \\ John L. Maron \\ University of Montana - Missoula, john.maron@mso.umt.edu \\ Michel Sallaberry A. \\ University of Pennsylvania
}

Follow this and additional works at: https://scholarworks.umt.edu/biosci_pubs

Part of the Biology Commons

Let us know how access to this document benefits you.

\section{Recommended Citation}

Myers, J. P.; Maron, John L.; and Sallaberry A., Michel, "Going to Extremes: Why Do Sanderlings Migrate to the Neotropics?" (1985). Biological Sciences Faculty Publications. 353.

https://scholarworks.umt.edu/biosci_pubs/353

This Article is brought to you for free and open access by the Biological Sciences at ScholarWorks at University of Montana. It has been accepted for inclusion in Biological Sciences Faculty Publications by an authorized administrator of ScholarWorks at University of Montana. For more information, please contact scholarworks@mso.umt.edu. 
Going to Extremes: Why Do Sanderlings Migrate to the Neotropics?

Author(s): J. P. Myers, J. L. Maron and Michel Sallaberry

Source: Ornithological Monographs, No. 36, Neotropical Ornithology (1985), pp. 520-535

Published by: University of California Press for the American Ornithologists' Union

Stable URL: http://www.jstor.org/stable/40168302

Accessed: 16/12/2013 14:47

Your use of the JSTOR archive indicates your acceptance of the Terms \& Conditions of Use, available at http://www.jstor.org/page/info/about/policies/terms.jsp

JSTOR is a not-for-profit service that helps scholars, researchers, and students discover, use, and build upon a wide range of content in a trusted digital archive. We use information technology and tools to increase productivity and facilitate new forms of scholarship. For more information about JSTOR, please contact support@jstor.org. 


\title{
GOING TO EXTREMES: WHY DO SANDERLINGS MIGRATE TO THE NEOTROPICS?
}

\author{
J. P. MYers ${ }^{1,2,3}$, J. L. MARON ${ }^{3,4}$, AND Michel SAllaberry ${ }^{1,2,5}$ \\ 'Academy of Natural Sciences, 19th and the Parkway, Philadelphia, Pennsylvania 19103 USA; \\ ${ }^{2}$ Department of Biology, University of Pennsylvania, Philadelphia, Pennsylvania 19104 USA; \\ ${ }^{3}$ Bodega Marine Laboratory, P.O. Box 247, Bodega Bay, California 94923 USA; \\ ${ }^{4}$ Biology Department, University of North Dakota, Grand Forks, North Dakota 58202 USA; and \\ ${ }^{5}$ Museo Nacional de Historia Natural, Casilla 787, Santiago, Chile
}

\begin{abstract}
Sanderlings (Calidris alba) breed within a small latitudinal range in the arctic while spreading in winter virtually throughout temperate and tropical marine beaches of the world. This paper examines spatial variation in Sanderlings nonbreeding density across the New World, documents annual cycle differences between populations wintering in California and those wintering in Peru and Chile, and then explores demographic and ecological factors underlying Sanderlings migration to different wintering grounds.

Densities during the nonbreeding season are higher on the Pacific coast than on the Atlantic at all censused latitudes in the New World, and reach a peak in southwestern Peru and northwestern Chile adjacent to the Humboldt Current. Populations wintering in California spend a larger fraction of the year on the wintering site than do those wintering in Peru and Chile. Adults replace primaries during prebasic molt in both regions, as do first-winter Sanderlings in Peru and Chile. First-winter birds in California do not molt primaries.

Comparisons of weight and time-activity budgets near the northern and southern ends of the winter distributions along the Pacific coast of the western hemisphere indicate that resource conditions are more favorable for Sanderlings in the south.
\end{abstract}

RESUMEN. Los playeros (Calidris alba) se reproducen en un rango de distribución latitudinal muy circunscripto en el ártico, mientras que en invierno se dispersan hacia las playas templadas y tropicales de los mares del mundo. Este trabajo examina la variación espacial en la densidad de playeros no anidadores en el Nuevo Mundo, presenta información sobre diferencias en los ciclos anuales entre las poblaciones que invernan en California y aquellas que invernan en Perú y Chile y así explorar factores demográficos y ecológicos fundamentando las migraciones de playeros a diferentes áreas de invernación.

Se observa que para todas las latidues censadas en el Nuevo Mundo las densidades durante la estación no reproductiva son mayores en la costa del Pacífico que en la del Atlántico, teniendo su pico máximo en el suroeste de Perú y el noroeste de Chile, adyacentes a la corriente de Humbolt. Las poblaciones que invernan en California pasan una mayor parte del año en el sitio de invernada que las poblaciones que invernan en Perú y Chile. Los adultos reemplazan las primarias durante la muda prebásica en ambas regiones tal como lo hacen los playeros jóvenes ("first-winter") que pasan su primera invernada en Perú y Chile. Los playeros que pasan la primera invernada en California no mudan las primarias.

Comparaciones del peso y patrones de actividad cerca de los límites norte y sur de las áreas de invernada a lo largo de la costa del Pacífico del hemisferio occidental indican que las condiciones de los recursos en el sur son mas favorables para los playeros.

Two salient features distinguish the distribution of Sanderlings (Calidris alba, Scolopacidae) in the New World. First, Sanderlings breed only in the high arctic. Second, during the nonbreeding season Sanderlings occur on temperate and tropical sandy beaches throughout the western hemisphere. Their broad winter range spans more than $100^{\circ}$ latitude and is among the widest of all migrant birds' nonbreeding ranges.

In this paper we consider two questions posed by these distributions. How does Sanderling density vary across their nonbreeding distribution, and why do some Sanderlings migrate much farther than others?

We begin by describing spatial and temporal features of Sanderling distribution in the west, 
including original data from the United States, Mexico, Ecuador, Peru, and Chile. We then develop a demographic and ecological framework for dissecting hypotheses concerning the evolution of long-distance migration. Finally, we present data on ecological benefits gained by long-distance migrant Sanderlings in Chile compared to California.

This essay is neither a traditional review nor a research paper. Instead, it lies between the two, synthesizing current knowledge about the migration and annual cycle of one species that is now the subject of intense investigation. We emphasize that these studies are as yet incomplete, and offer this paper here to provoke parallel work with other species and to stimulate alternative approaches to the study of the evolution of migration.

The approach we take is reductionistic. Moreover, it concentrates on one species in order to avoid two pitfalls we believe have retarded progress in studies on the ecology and evolution of migration. The first is a confused intertwining of demographical and ecological hypotheses. The second is the unrealistic supposition that the behavior of all migratory species represents a cohesive evolutionary response to the same ecological factors. These pitfalls make it unlikely that a holistic approach to an entire migration system will yield anything but murky waters and untestable-even if appealing - assertions. We need to begin by understanding the migration of one species.

\section{PART I. THE GEOGRAPHY AND TIMING OF SANDERLING MIGRATION METHODS}

\section{Censuses}

Sanderlings restrict their activities almost exclusively to sandy beaches and sandflats. The latter are covered by incoming tides. It is thus possible to determine local density in a simple fashion by making counts during a period of the tidal cycle when all members of the local population are forced by high water onto the beach (Connors et al. 1981).

Most censuses summarized in this paper were conducted on foot along a predetermined length of beach by tallying Sanderlings encountered. Birds flying past the observer from behind (i.e., from a section of the beach already censused) were subtracted from the total. Birds flying in the opposite direction were added. Censuses conducted by car were made by driving along the beach with two or more observers, one or more counting while one drove.

Censuses at Bodega Bay, California, were made over the years 1976 to 1982, with one to four censuses made each month in a given year. We distinguished adult from first-winter birds during counts in early fall using plumage characters (Prater et al. 1977). After October, these groups cannot be distinguished consistently in the field. Other sites along the United States Pacific Coast were censused by a network of 31 collaborating volunteers during mid-January 1982. Sites on the Pacific coast in South America were censused by the authors and assistants in February-March 1982 and December 1982. C. T. Schick, T. Johnson, and M. Kunde censused beaches in Baja California in December 1983. Myers censused beaches near Veracruz, Mexico in December 1983. Census data for January-February 1982 in North Carolina were obtained by J. R. Walters (1984). B. R. Chapman (1984) censused Texas beaches during midwinter of 1980 and 1981 . R. I. G. Morrison (1984) provided data from aerial censuses along the South American Atlantic and Caribbean coasts during January-February 1982.

Lengths of beach censuses were, North America: Washington, $96 \mathrm{~km}$; Oregon, $71 \mathrm{~km}$; Northern California, $103 \mathrm{~km}$; Southern California, $26 \mathrm{~km}$; North Carolina, $9 \mathrm{~km}$; Texas, 190 km; Baja California, $543 \mathrm{~km}$; Veracruz, Mexico, $35 \mathrm{~km}$; and Neotropical America: Ecuador, $8 \mathrm{~km}$; Peru, $55.4 \mathrm{~km}$; Northern Chile, $31 \mathrm{~km}$; North Central Chile, $11.4 \mathrm{~km}$; Central Chile, $16.9 \mathrm{~km}$; Southern Chile, $9 \mathrm{~km}$; Tierra del Fuego, $15 \mathrm{~km}$; Peninsula Valdez, Argentina, 19 km; Bahia Blanca, Argentina, 83 km; Porto Alegre, Brazil, 127 km; San Luis, Brazil, 34 km; mouth of Amazon, Brazil, $55 \mathrm{~km}$; Surinam, $27 \mathrm{~km}$; Venezuela, $280 \mathrm{~km}$.

\section{MolT}

Primary molt scores were obtained for all birds captured for banding. Each primary on the right wing was examined and assigned a score based on the proportion of growth of new primaries: 0 if old or missing, 0.1 to 0.9 for one-tenth to nine/tenths or more grown, 10 if fully grown. A feather was considered old if it was one of the primaries on the wing during the previous southward migration. A molt score for the bird varying between 0 and 10 was then calculated by summing the scores for each primary. The goal of this simplified molt 


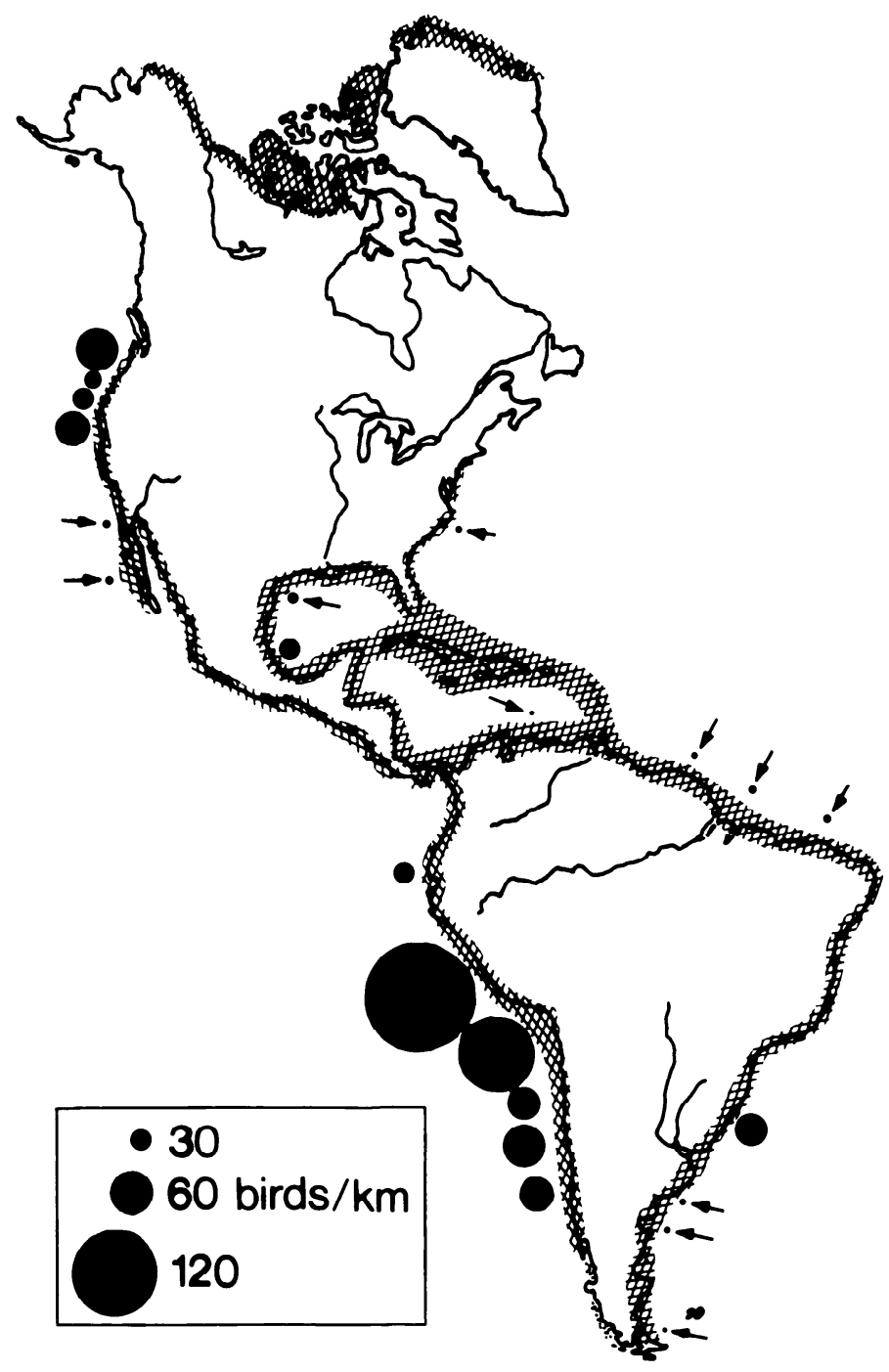

Fig. 1. Sanderlings distribution in the Western Hemisphere. Hatching in Arctic: breeding. Hatching along temperate and tropical coastlines: nonbreeding. Nonbreeding density (birds $/ \mathbf{k m}$ ) on censused outer coast sandy beaches proportional to the diameter of circle adjacent to the coastal census site. Arrows point to census results that might otherwise be missed because of low density. Coastal sectors without adjacent circles were not censused.

score method was merely to document when primary molt occurred in different age classes at different locations. Sites from Peru and Chile were pooled for comparison with California.

\section{RESULTS}

\section{GEOGRAPHY}

Sanderlings breed throughout the Holarctic Region chiefly north of $73^{\circ} \mathrm{N}$ (Bent 1927 ; Glutz von Blotzheim et al. 1975; Cramp 1983). Within the western hemisphere (Fig. 1) their breeding distribution is limited mostly to the Canadian arctic islands and Greenland, although they do breed at low densities in Alaska (Godfrey 1966; Pitelka 1974). During the nonbreeding period, they are found along most temperate and tropical marine beaches of the world, from $50^{\circ} \mathrm{N}$ on the Pacific Coast and $35^{\circ} \mathrm{N}$ on the Atlantic south to $50^{\circ} \mathrm{S}$. This species' winter distribution thus spans some $80^{\circ}$ to $100^{\circ}$ latitude, in contrast to its narrow latitudinal breeding range. 
How breeding populations array themselves on the wintering ground is virtually unknown, save migration by Greenland-breeding Sanderlings to the Old World (Branson 1979). Whether significant numbers from Siberian breeding grounds reach the western hemisphere in winter is uncertain. Individuals from some Siberian breeding populations migrate to Europe (Glutz von Blotzheim et al. 1975; Branson 1979). Preliminary data (Myers et al. 1984) on the movement of marked individuals indicate that populations wintering along the Pacific Coast of South America move north through the United States chiefly via two routes, along the Pacific coasts of California, Oregon, and Washington, or along the gulf coast of Texas. A few travel via the Atlantic coast.

Midwinter population densities within the Western Hemisphere are consistently higher along the Pacific than along the Atlantic coast at all latitudes, and higher in the southern hemisphere than in the Northern (Fig. 1). The largest known wintering populations are found in coastal Peru and northern Chile, adjacent to the Humboldt Current. Unfortunately, data are lacking for most of Central America.

Throughout the nonbreeding range of Sanderlings, local populations contain adults and juveniles, males and females. Myers (1981a) reported that sex and age classes do not segregate latitudinally, save for a slight but significant tendency for first-winter males to winter farther south than first-winter females. This separation is small compared to the overall latitudinal spread of the species during the nonbreeding season.

Important spring staging areas have been identified along both coasts in North America. On the Pacific, two sites are known. The more southern of these includes beaches within the Oregon Dunes National Recreation area and then beaches from northern Oregon to Gray's Harbor in southern Washington, especially around the mouth of the Columbia River (Myers et al. 1984). At least 30,000 Sanderlings passed through these areas in spring 1983. The second Pacific staging site lies to the north in the Copper River Delta of Alaska, where single flocks of 10,000+ Sanderlings have been observed (Isleib 1979). On the Atlantic coast, Sanderlings spread widely along the outer coast beaches from North Carolina to New Jersey, with a major concentration in Delaware Bay. At least 50,000 Sanderlings stage here in spring migration (Dunne et al. 1982).

No fall staging areas of comparable magnitude have been reported.

\section{SEASONALITY}

Numbers. - Adult Sanderlings begin returning to northern wintering grounds in central coastal California by mid-July (Fig. 2). Among the first adults to return are individuals that will remain throughout the nonbreeding season. For example, on 17 July 1982, of 17 Sanderlings present at Bodega Bay, four had been color-banded at Bodega Bay during previous years. These banded individuals then remained throughout the 1982-1983 winter in the area (although see Myers 1984 on regional vagility of the Bodega Bay population). The 1:4 ratio of banded to unbanded birds is typical of the ratio prevailing at Bodega during the winter, suggesting that all 17 could have been local winter residents.

The major influx of adults begins in early August, and by October most have returned. Increases in adult population size at Bodega Bay during fall and early winter reflect two processes, revealed by studies of individually color-marked birds (Myers 1980a, 1984). First, newly returning adults continue to appear through December, although at much lower rates than in September and October. In many instances, these new returnees actually had been sighted at nearby estuaries in central California for a month or more, but simply had not reappeared at Bodega Bay. Second, in late summer and early fall, returned adults wander broadly along the central California coastline, staying for a few days or weeks at Bodega Bay, moving away for a period, and then returning (Myers 1984). Through September and October, the proportion of time spent away decreases, with the result that a greater fraction of the Bodega Bay adult population is present at a given time during late fall and winter.

The first juveniles begin trickling in by late August (Fig. 2). Here, as with adults, among the first birds are individuals that will remain until spring departure (Myers, unpubl. data). Numbers build rapidly in September. Beyond mid-October it is impossible to differentiate adults and juveniles during a census.

The combined adult/first-winter population builds through November, declines slowly through the winter, and then drops rapidly in spring. During some years in March, large portions of the Bodega Bay population move to an outer beach approximately $20 \mathrm{~km}$ south, out of the census area but still in central coastal California. The early spring decline (Fig. 2) 


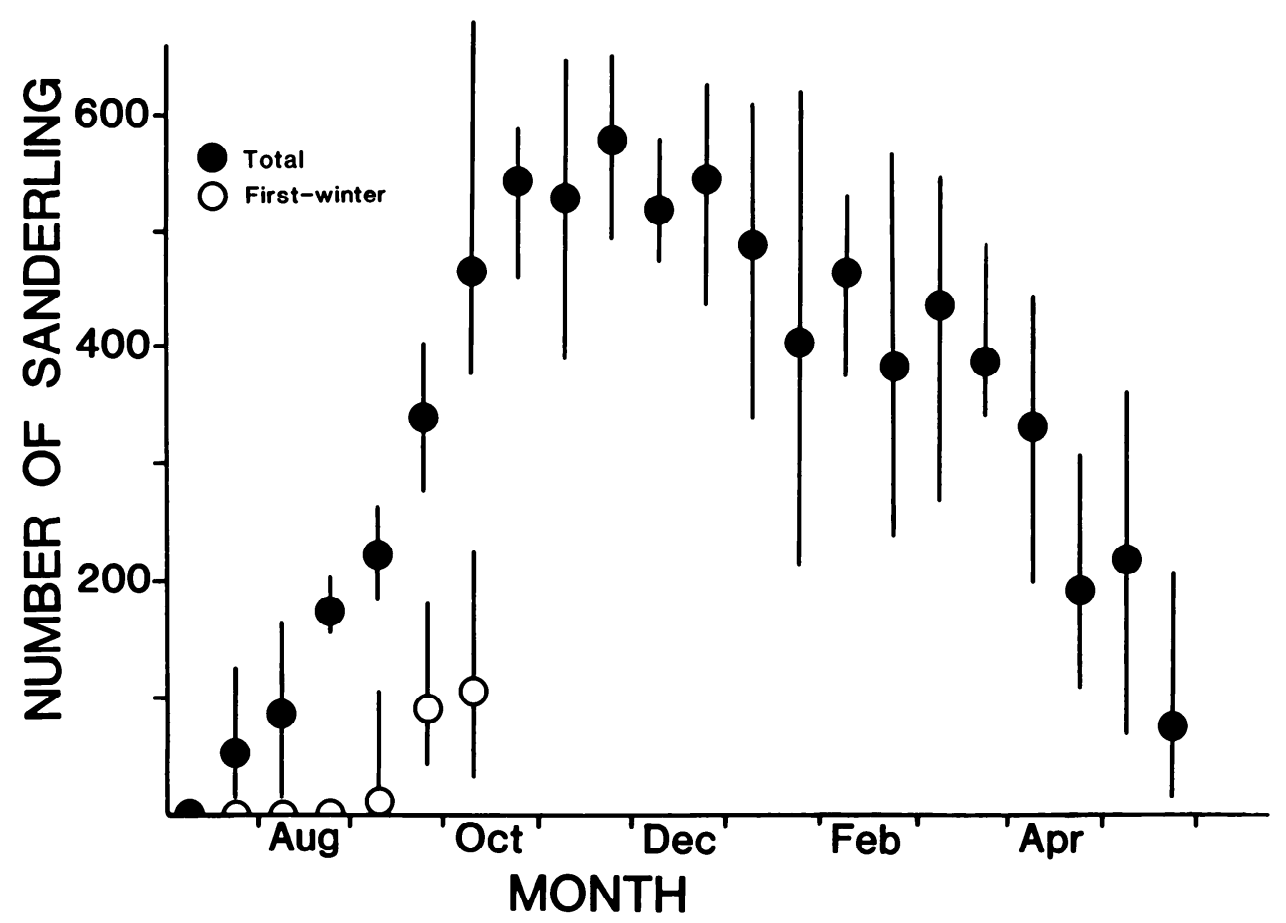

FIG. 2. Mean number and range of Sanderlings at Bodega Bay, California during the years 1976 to 1983. Solid circles: total population. Open circles: juveniles. Adults and juveniles cannot be distinguished reliably in the field after mid-October.

therefore, does not reflect migration. Movement north begins in April or early May, and virtually all individuals are gone by late May. Detailed records of departure times of individually color-banded birds at Bodega Bay reveal no striking age difference in departure schedule (Myers, unpubl. data).

The period of winter residency for many individuals at Bodega Bay thus lasts nine months and for some reaches ten.

Far less information is available on seasonality in southern populations, but patterns differ in at least two respects. First, arrival on the wintering grounds is later. Second, a large number of birds remain on South American wintering grounds during the breeding season, June through mid-July. These points are amplified below.

Adults begin arriving by early September whereas juveniles first appear in early October. Preliminary observations during autumn 1983 of birds color-marked in Peru and Chile during the nonbreeding season of 1982-1983 indicate that birds wintering in South America may spend up to a month or more in stopovers along the United States east coast. Individuals banded in Peru and Chile were seen as late as early September at sites between Florida and Prince Edward Island, Newfoundland. Moreover, birds banded the previous winter in northern Chile have been detected at stopovers in Peru on their way south the following fall as late as October (Myers, unpubl. data).

Local populations in Peru remain high through the end of March. Censuses near Lima begun in April 1983 indicate that numbers fall steadily through April, and that most individuals have left by the end of the month (G. Castro and E. Ortiz, pers. comm.).

Many Sanderlings in the southern hemisphere oversummer, failing to migrate north for the arctic breeding season. Such behavior is common in many shorebird species, particularly Southern Hemisphere migrants (Eisenmann 1951; Johnson 1979; Myers 1981b). R. A. Hughes (pers. comm.) reported flocks of Sanderlings at Mollendo, Peru during each northern summer, and also that several thousand Sanderlings oversummered at Tacna on the southern Peruvian coast in June 1982. William Belton (pers. comm.) reported similar observations for south- 


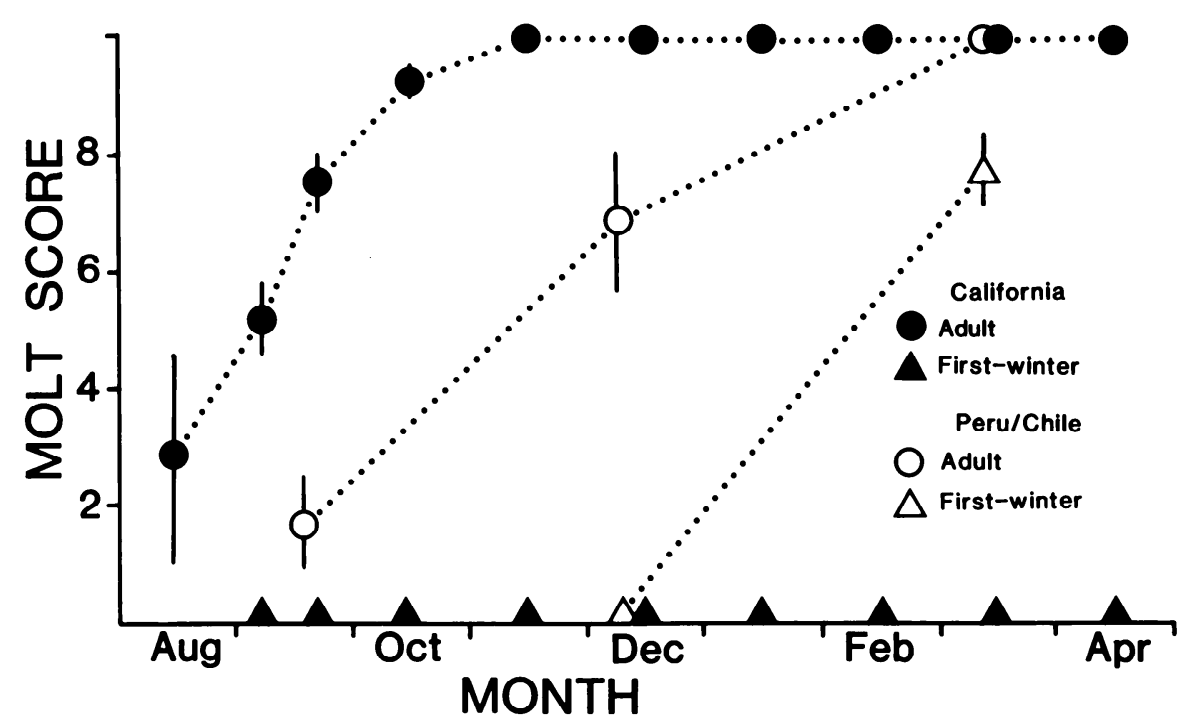

FIG. 3. Primary molt of Sanderlings in California and northwest Chile/southwest Peru.

eastern Brazil. Judging from work with other long-distance shorebird migrants (Elliot et al. 1976; Johnson and Johnson 1983), many Sanderlings are not likely to return north in their first summer.

Molt. - At Bodega Bay, post-nuptial body molt begins immediately after a bird reaches the wintering site (Myers, unpubl. data). By early September it is completed in all adults. Primary molt starts shortly after a bird returns to Bodega Bay (Fig. 3). By late September virtually all adults have begun primary molt, and many have finished. A few individuals drag the process through to December, but most complete primary molt by mid-October. Juveniles at Bodega Bay commence their first-winter molt shortly after arrival, changing most body feathers by early December. Juveniles do not molt their remiges during their first winter (Fig. 3) and retain some wing and upper tail coverts until the following summer or fall.

Along the coast of southern Peru and northern Chile, adult primary molt takes place in late fall and early winter, with a few completing it as late as mid-March (Fig. 3). By mid-March most have begun molting contour feathers to alternate plumage. Most juveniles are in body and primary molt in March, when they still retain a mixture of old and new wing and tail coverts. Some replace all their primaries while a low proportion $(<1 \%)$ replace only the outer three. The body molt of almost all first-winter birds is to basic plumage.

\section{PART II. WHY DO SOME SANDERLINGS MIGRATE FARTHER THAN OTHERS?}

The combination of a narrow breeding latitudinal range and a broad winter range means that some Sanderlings migrate much farther than others. Birds wintering in central Chile may travel $7500 \mathrm{~km}$ beyond potential wintering sites in the northern hemisphere. The round-trip costs of that extra distance at $65 \mathrm{~km} / \mathrm{hr}$ involve $230 \mathrm{hrs}$ of flight and an estimated 1242 kilocalories (after McNeil and Cadieaux 1972), or almost 6000 10-mm long sandcrabs (Emerita analoga, Hippidae), each worth about 300 calories (Myers and Smith, unpubl. data), assuming 70 percent assimilation efficiency. These calories are roughly equivalent to a month's existence costs for a $50 \mathrm{gm}$ Sanderling in mid-winter in California (calculated after Kendeigh et al. 1977). This is surely a simplistic assessment, as it assumes similar metabolism for migrants and winter residents and does not take into account non-caloric costs. Moreover, it implies that the calories are of consequence to the migrating individual, or in other words, that energy is one of the factors limiting migration. As a starting point, nonetheless, it conveys the magnitude of additional costs imposed by migration to southern wintering areas.

Why do so many Sanderlings bother to go to the Neotropics? In essence, studies of the evolution of migration focus on two broadly intertwined questions, (1) why migrate and, (2) 
if you migrate, where should you go? Clearly, the range of possibilities for (2) will influence (1), as formalized by Lack (1954) and later by Cohen (1967), Southwood (1977), Baker (1978), Dingle (1980), and others. Unfortunately, the field languishes far behind studies on migratory orientation, remaining poor in data and rife with imprecise theory (Dingle 1980; Gauthreaux 1982).

Modern theoretical approaches to the study of evolution of avian migration have had two components. The first is the demographic consequence of a given migratory option: mortality costs of increasing migration distance and productivity or survivorship gains that result from remaining in or moving to different wintering or breeding areas (Lack 1954, 1968; Salomonsen 1955; Cohen 1967; Haartman 1968; Baker 1978; Fretwell 1980; Greenberg 1980; Ketterson and Nolan 1982). The second is the ecological basis for the demographic effect, for example, resource availability (Blondel 1969; Gauthreaux 1978; Fretwell 1980), predation (Fretwell 1980), competition (Salomonsen 1955; Cox 1968) or environmental predictability (Alerstrom and Enckell 1979).

\section{DEMOGRAPHIC MODELS}

For birds with a life cycle such as that of the Sanderlings, migratory behavior potentially can affect a suite of demographic components that contribute to an individual's lifetime reproductive success. Figure 4 summarizes the annual demographic cycle of a Sanderling, focusing explicitly on those components liable to be affected by migration:

(1) survivorship from the time of arrival on the wintering ground to the time of departure, hereafter referred to as within-winter survivorship, $S_{w}$, at a particular wintering site for birds of a given age and sex;

(2) age, sex and distance-specific survivorship during northward migration, $S_{n}$;

(3) the age, sex and distance-specific probability of obtaining a breeding opportunity, B;

(4) the age, sex and location-specific effect that winter resources may have on breeding condition, E;

(5) age, sex and location-specific seasonal productivity, in terms of the number of progeny surviving to southward migration, $P$;

(6) age, sex and location-specific survivorship on the breeding ground for a given level of reproductive effort, $\mathbf{S}_{\mathbf{b}}$;

(7) age, sex and location-specific survivorship when oversummering south of the breeding ground, $\mathrm{S}_{\mathrm{o}}$;

(8) age, sex and distance-specific survivorship during southward migration, $S_{\mathrm{s}}$.

Beginning when individuals reach the wintering ground, within-winter survivorship, $S_{w}$, sets the probability that an individual will survive through the winter. Come spring, surviving individuals may either migrate north, thus accepting the risks of migration plus the potential benefits of breeding, or they may remain south of the breeding ground. In such a decision, whether made in ecological or evolutionary time, the likelihood of successful reproduction (given $S_{n}, E, B, S_{b}, P$, and $S_{s}$ specific to their age, sex, winter location and migration distance) must be weighed against the $S_{o}$ and the probabilities for future reproductive opportunities (i.e., survival through another winter and migration plus successful reproduction).

$S_{n}, B$, and $E$ together determine the probability and quality of reproductive effort. The latter two require additional comment. $B$ refers to the effect that distance between wintering and breeding grounds may have on productivity by affecting time of arrival and thereby obtaining essential breeding resources such as a territory or a mate (Myers 1981a). The magnitude of $B$ is unknown and its potential importance debated (Ketterson and Nolan 1983). E refers to the enhancement of breeding effort engendered by energy or nutritional reserves stored when on the wintering ground and mobilized during the breeding season. This phenomenon is well known in geese (Drent and Daan 1980) and may contribute to the differential attractiveness of different wintering areas. For Sanderlings in particular it seems unlikely to be important, as migration consumes more calories than can be stored on the wintering ground (see above). Thus, an individual could not carry stored reserves northward. Nutritional factors other than calories may be important, even though for Sanderlings it seems implausible because of the broad similarity of their diets-cirolanid isopods, amphipods, Emerita-throughout their winter distribution.

Demographic models of avian migration have considered two types of tradeoffs (Fig. 4), migration survivorship $\left(S_{n} \times S_{s}\right)$ played against winter survivorship $\left(S_{w}\right)$ and against produc- 


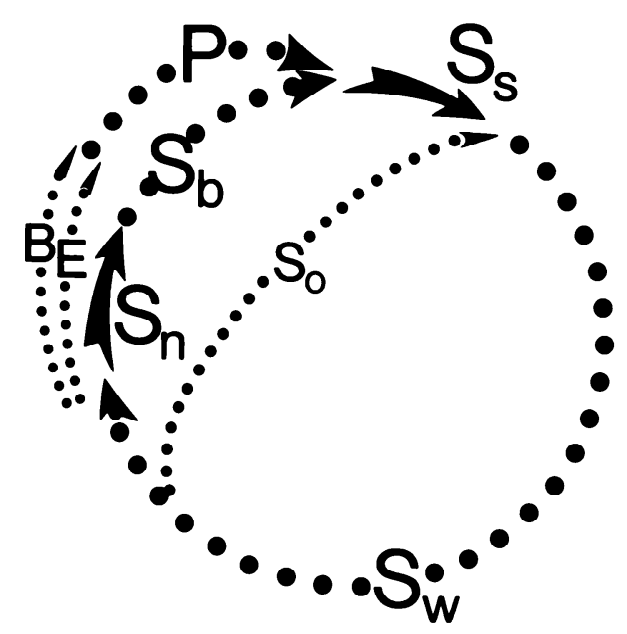

Fig. 4. The annual cycle of Sanderling demography. See text p. 526 for explanation of symbols.

tivity (P) (Cohen 1967; Haartmann 1968; Lack 1968; Fretwell 1980; Greenberg 1980; Ketterson and Nolan 1982). One assumption underlies virtually all interpretations and models, that $S_{w}$ increases monotonically with distance, or increases to some peak determined by the geographic distribution of optimum breeding or wintering grounds. Most interpretations also assume that $S_{n}$ and $S_{s}$ decrease with migration distance. $P$ may increase or decrease with distance, depending upon the model and the pattern being explained; viewing the breeding grounds as the starting point, $P$ may decrease with distance if, by wintering farther from the breeding area, an individual lessens its chance of obtaining a breeding site (Haartman 1968) or has a shorter breeding season (Greenberg 1980, see below). Viewing the wintering grounds as the starting point, then $P$ may increase with distance migrated if, by migrating farther, individuals obtain more resources essential for breeding or reduce nest predation (Cox 1968; Fretwell 1980). Alternatively, $P$ may decrease at greater distances from wintering sites if individuals lose winter site dominance (Fretwell 1980). Depending upon the taxon involved, either starting point may be plausible. For Sanderlings, viewing the arctic breeding grounds as the starting point is appropriate, as all 24 members of the calidridine sandpipers breed in the arctic (Myers 1981b), and the vast majority of scolopacids nest in the northern hemisphere (Myers 1980b).

Despite the fundamental importance to theory of these tradeoffs, few studies address them empirically. The best data are those of Ketterson and Nolan (1982), indicating (1) that $S_{w}$ of southern wintering populations of Dark-eyed Juncos (Junco hyemalis) exceeds $S_{w}$ of northern wintering populations and (2) that annual survivorship $\left(S_{w} \times S_{n} \times S_{b} \times S_{s}\right)$ of southern wintering populations equals that of northern populations. This finding implies higher mortality for the southern birds during another period of the year. Ketterson and Nolan propose that the southern birds have higher mortality during migration, in other words, that $S_{n}$ or $S_{s}$ or both decrease with migration distance. Ketterson and Nolan's work is the first empirical migration study making a concerted empirical effort to partition survivorship into its annual components (Fig. 4). Their data, however, are limited and are poor at distinguishing dispersal from mortality. Moreover, the results imply a perfect tradeoff between survivorship during migration $\left(S_{n} \times S_{s}\right)$ and winter survivorship $\left(S_{w}\right)$, which seems implausible.

Greenberg (1980) showed that the average North American migrant passerine has higher adult survivorship and lower productivity than does the average resident. This conflicts with O'Connor's (1981) demographic analysis of British migrants and residents. O'Connor found no difference in either survivorship or productivity, yet argued that migrants are r-selected while residents are k-selected. Both studies are marred by statistical problems. Greenberg's sample is geographically heterogeneous, while O'Connor's sample is taxonomically so, and neither O'Connor nor Greenberg controls for a positive relationship between body size and survivorship (e.g., Boyd 1962). Greenberg's results would probably be strengthened by this and O'Connor's weakened, because in both samples the residents are larger on average than 
the migrants. Finally, and most critically in the current context, neither study can partition survivorship among periods of the year. As a result, whether migration entails a tradeoff between within-winter survivorship and the costs of migration remains unresolved.

Greenberg argued through a graphical model that long-distance migrants have an enhanced $S_{w}$ not simply because their instantaneous winter survivorship rate is higher. He proposed they have longer nonbreeding seasons because they reproduce in regions with shorter breeding seasons, and that as a result, they have more time to benefit cumulatively from a high instantaneous survivorship rate. This retrospectively predicts leap-frog migration patterns (e.g., Swarth 1920; Myers 1981b). Data from Sanderlings, however, contradict this aspect of Greenberg's model; as developed in the first section, individuals wintering in Peru spend less time on the wintering ground than those wintering in California.

Baker (1978) provides an ambitious logical framework for considering the evolution of migration. At an empirical level, however, his largely untestable general framework reduces to questions about the ultimate demographic consequences of juveniles settling in particular areas.

\section{ECOLOGICAL FACTORS}

Given that some demographic differences must exist among populations with different migratory tendencies, the question becomes what ecological factors underlie the demography. This question has been approached from a number of directions.

MacArthur (1959) and others (e.g., Willson 1976; Herrera 1978; Alerstrom and Ecknell 1979) have examined the geographic distribution of migrants in relation to ecological factors. These reviews address the first question above, i.e., why migrate, and the results clearly implicate seasonal patterns in the abundance and predictability of resources. Tundra insectivorous birds, such as Sanderlings, may leave the arctic during winter because of the disappearance of their food supply. But the question is more complex in regions with mixtures of migrant and resident species (e.g., MacArthur 1959), or for species with some resident and some migratory populations (Swarth 1920), or populations with both resident and migrant fractions (Nice 1937; Haartman 1968). Suddenly the self-evident conclusions disappear and the generalizations such as Lack's (1968), that "migration occurs in those species which survive in greater numbers if they leave, than if they remain in, their breeding grounds for the nonbreeding season," beg empirical documentation.

More focused ecological papers typically have argued for the primacy of one or a few factors. Their conclusions have rested more upon logic, untested assumptions and theory than upon data. The majority ultimately derive from seasonal patterns of resource availability and several interpretations seem plausible. Resource-based interpretations include hypotheses on competition (Cox 1968), behavioral dominance (Haartman 1968; Fretwell 1969, 1980; Gauthreaux 1978, 1982), and resource phenology (Klopfer et al. 1974). One less frequently mentioned alternative is predation, with geographic gradients in nest predation risk favoring migration from the optimum (determined by resources) wintering grounds (Fretwell 1980).

As attractive as these ideas are, the work to date fails to discriminate among competing ecological hypotheses that would provide a connection to demographic models. It assumes a common cause for migration across many taxonomic groups whose geography, ecology, and history differ radically. We are left unable to specify the immediate ecological costs or benefits of reaching alternative breeding or wintering grounds, because little has been done to test the empirical importance of ecological variables underlying choices between alternative wintering sites.

\section{Ecological Differences Among Sanderling WINTERING SITES}

For Sanderlings along the Pacific coast we can list four hypotheses that predict differences among sites in $S_{w}$ : (1) milder physical conditions result in reduced physiological stress for birds in South America; (2) predation rates are lower in South America; (3) resource availability is higher in South America and therefore mortality due to starvation is lower; and (4) resources are more stable in South America resulting in lower starvation rates.

The first, while relevant to Sanderlings' global distribution in winter, probably is not important to the immediate question: why do so many Sanderlings migrate to the Neotropics? Many geographic locations north of the Neotropics have environments within Sanderlings' physiological limits; 70 percent of the adult Sanderlings present at Bodega Bay, California 
during the fall remain there during winter and return again the next fall (Myers 1980a). Thus, the birds wintering in Chile almost certainly could survive the environmental conditions of a California winter.

The other hypotheses cannot be rejected given current data. Raptor predation on shorebirds is heavy in central coastal California (Page and Whitacre 1975) and predation risk may vary geographically because of the distribution of Sanderling predators. In fact, one of the primary Sanderling predators of the northern hemisphere, the Merlin (Falco columbarius), rarely migrates south beyond Panama (R. S. Ridgely, pers. comm.), and there is no clear ecological equivalent beyond Panama. On the other hand, another major predator of Sanderlings in the northern winter, the Peregrine Falcon (Falco peregrinus), migrates throughout South America in winter and is conspicuously common for this species along the Pacific shore adjacent to the Humboldt Current, where it regularly hunts Sanderlings and other northern migrants (Myers et al. 1984). Distribution patterns alone will not resolve the issue. Rather, we need data on mortality due to predation and the risk run by individuals in different wintering areas.

The remaining hypotheses focus on whether resource conditions are more favorable in the south, and if so, why? The third refers to a difference in resource availability. This might come about because of higher resource abundance in the south, because of latitudinal variation in other factors mediating resource availability independent of abundance (see Myers et al. 1980), because of lower competitor density and, thus, even with equivalent resource abundance, a higher per capita resource level, or some combination of them all. Competitors could be hetero- or conspecific.

The fourth hypothesis proposes that resource levels are less variable in Chile and Peru than those in California. The benefit for traveling to the Neotropics thus results from the reliability of food resources, even if average food availability is equal to or lower than that farther north (i.e., hypotheses 3 and 4 are distinct). Such differences in resource reliability are plausible, as winter storms beset California beaches frequently while coastal sites in southwest Peru and northwest Chile have not experienced a single storm during the last 30 years (R. A. Hughes, pers. comm.). Storms, especially with strong winds, disrupt shorebird feeding (Davidson 1981a; Dugan et al. 1981). The waves that accompany them also radically alter beaches and, thus, Sanderling prey distributions (Myers et al. 1981). On the other hand, every six to seven years an El Niño Current wreaks profound changes in the Peruvian and northern Chilean coastal ecosystem. In early 1983 coastal water temperatures throughout Peru exceeded normal by $5^{\circ}$ to $7^{\circ} \mathrm{C}$, an increase accompanied by massive die-offs in different invertebrate species, most notably the clam Mesodesma donacium, a dominant member of the sandy beach invertebrate fauna (R. A. Hughes, pers. comm.). The magnitude of effect on sandy beach crustaceans such as Emerita is unknown.

Clearly, none of the four hypotheses has been tested adequately for Sanderlings, nor for any other migrant. We present here preliminary data that indicate that food availability is higher in coastal Chile and Peru than in California, even though potential competitors on sandy beaches are more abundant.

\section{MeTHODS}

Allocation of time to foraging. - In northern Chile (December 1982) and in central coastal California (January 1983), we measured the proportion of birds foraging versus roosting during censuses taken throughout the day at two-hour intervals. In both areas, we covered all occupied Sanderling habitat during these censuses. In Chile (near Hornitos, $22^{\circ} \mathrm{S}$ ) one observer sampled three separate beaches totaling $12 \mathrm{~km}$ while riding a 3-wheel all-terrain vehicle. In California (Bodega Bay, $35^{\circ} \mathrm{N}$ ) four observers sampled two beaches $(7 \mathrm{~km})$, a slough $(\sim 1 \mathrm{ha})$ and a sandflat ( $\sim 200 \mathrm{ha})$ on foot and by spotting scope from a car. Censuses were run throughout the day on two different days at each site: one day with high tide in the morning, the other with high tide in afternoon.

Comparison of weights. - Sanderlings were captured (Myers and Sallaberry 1984) from night roosts (Chile and California) and from daytime foraging areas (Chile), weighed to the nearest $0.5 \mathrm{~g}$ with Pesola scales, and measured for tarsus, flattened wing chord, and bill length (proximal end of nares to tip). Weights were corrected for weight loss between time of capture and weighing using data from Schick (1983) and unpublished data from Bodega Bay. The California sample included all Sanderlings caught for banding at Bodega Bay in mid-winter from 1976 to 1983. Chilean birds were caught during December 1982.

Captured birds were grouped on the basis of capture site: natural feeding sites in California, 


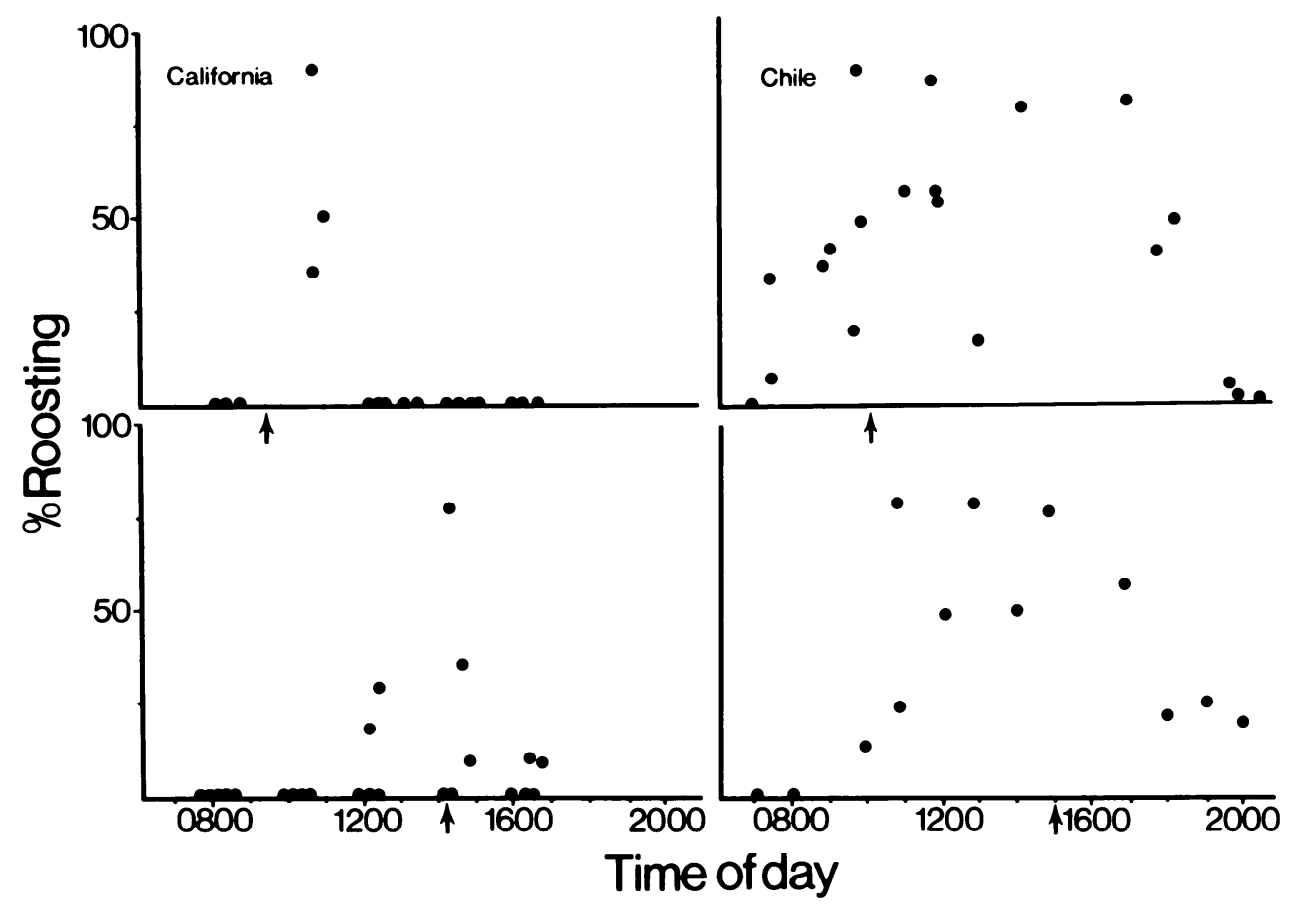

Fig. 5. Diurnal roosting pattern of Sanderlings in two different wintering populations. Graphs show the percentage of birds that were roosting during each census. Time of high tide indicated by arrow. Left: Bodega Bay, California; upper, 12 January 1983; lower, 4 January 1983. Right: Hornitos, Chile; upper, 16-17 December 1982; lower 22 December 1982.

natural feeding sites in Chile, and artificial feeding sites in Chile. The latter birds were all feeding on fish meal spilled in the yard of a fish processing plant near Mejillones (22 5 ), approximately $25 \mathrm{~km}$ south of the natural feeding site (Hornitos). They had access to food ad libitum, and alternated between feeding on piles of spilled fish meal in the yard and bathing and roosting on the shore nearby.

To compare the weights of birds in these groups we performed an analysis of covariance to control for the relationship between size and weight and possible body size differences between California and Chile. Tarsus length was the covariate. Differences between weights were then tested using a Student-Newman-Keuls test. All statistical tests were run at The University of Pennsylvania Computing Center using the statistical package SAS.

\section{Allocation of Time to Foraging}

Figure 5 shows the proportion of birds roosting at different portions of the tidal cycle and at different times of day in California (January 1983) and in northern Chile (December 1982). The Chilean population sampled was feeding on natural prey, not at the fish meal factory. The Sanderlings in California roosted only around high tide, independent of the time of day. The Chilean birds, by contrast, began roosting within an hour after sun-up, and at any given time throughout the day a large fraction of the local population was roosting. This fraction decreased appreciably only just before dusk. They did not adjust to the changing tide schedule.

No quantitative samples were obtained at either location on night-time foraging. However, throughout these periods we attempted to capture birds at night roosts. During December 1982 in Chile, we searched over $35 \mathrm{~km}$ of beach during the night with a 300,000 candlepower spotlight. Less than one percent of the daytime population was observed on the beach at night, and most of the birds were roosting. Fieldwork in December 1983 revealed that they roost several hundred meters inland. At Bodega Bay, we regularly patrolled the beaches at night with a 300,000 candlepower spotlight. Here, most individuals within the local population 
TABLE 1

Weights of SANderlings Feeding Under Different Conditions ${ }^{1}$

\begin{tabular}{|c|c|c|c|}
\hline & Mean & s.e. & $\mathbf{N}$ \\
\hline \multicolumn{4}{|c|}{ Adult } \\
\hline California & 48.7 & 0.4 & 118 \\
\hline Chile-natural & 51.5 & 1.2 & 7 \\
\hline Chile-ad libitum & 55.6 & 1.1 & 39 \\
\hline \multicolumn{4}{|c|}{ First-winter } \\
\hline California & 48.5 & 0.5 & 91 \\
\hline Chile-natural & 54.1 & 0.9 & 19 \\
\hline Chile-ad libitum & 57.3 & 0.4 & 262 \\
\hline
\end{tabular}

' Weights in grams; s.e. $=$ standard error.

roost during mid- and high tide levels at night, often all in one single flock. During low tides at night, however, the roost is much more difficult to locate, and a portion of the population can be found feeding on exposed sandflats.

Taken together, the data for daylight foraging and the observations during night hours clearly show that Chilean birds spend far less time feeding than do individuals in California.

\section{COMPARISON OF WEIGHTS}

We compared weights of naturally-feeding Sanderlings in California and Chile and Chilean birds feeding at an artificial, superabundant food resource (Table 1). For first-winter birds, after removing tarsus as a covariate, the overall $\mathrm{F}$ for location was $86.1(P<0.0001)$. The Student-Newman-Keuls test revealed that California first-winter birds were lighter than both sets of Chilean first-winter birds. Chilean birds feeding naturally, in turn, were lighter than those feeding ad libitum. For adults, again after removing tarsus as a covariate, the overall $F$ for location was $33.7(P<0.0001)$. Among the adult birds, those in California did not differ from naturally-feeding birds in Chile but both of these were lighter than the birds feeding on fish meal. Unfortunately, the sample of naturally-feeding adults in Chile is too small to accept this conclusion without reservation. The trends in weights for adults follow those for juveniles.

\section{DISCUSSION}

We interpret these results to indicate that resource conditions during the mid-boreal winter are more favorable in Chile than in California for both adults and juveniles. Even though weights of the naturally-feeding adults in the two areas did not differ statistically, the California birds required more foraging time to achieve those weights. Furthermore, the ad libitum data imply that natural food is not superabundant in Chile. Given free food, both adults and juveniles weigh more.

A suite of untested assumptions underlies the above interpretations, the most important of which is that relative body weight indicates resource conditions. This can be true, but it is not a simple issue (e.g., Blem 1981). The weights of the ad libitum birds are consistent with this assumption, in that they are greater than those of birds without superabundant food; experiments with caged shorebirds yielded similar results (Goss-Custard et al. 1981; Myers and Williams, unpubl. data). Weights of European waders in the wild decrease during periods of food stress (Davidson 1981a, 1982; Dugan et al. 1981). Alternatively, it has been argued that shorebirds are more likely to store fat when resource conditions are unpredictable and the likelihood of periods of starvation is high (Evans and Smith 1975; Davidson 1981b; but see above re resource predictability).

If the bird weights do reflect different resource conditions, then these differences could result from geographic differences in resource availability, in competition, or both. These two factors can be distinguished, although they are not mutually exclusive. The question is whether either of them, in itself, is both necessary and sufficient to explain the observed patterns. Differences in resource availability do not necessarily invoke a notion of Sanderling density. To date we lack direct comparative measurements of prey availability in the two locations, and they will be difficult to obtain because of problems inherent in measuring food availability from the birds' point of view (Myers et al. 1980). 
TABLE 2

Linear Densities of Birds TAking INTertidal InVertebrates on SANDy Beaches During MID-BOREAL WINTER

\begin{tabular}{lcccc}
\hline \hline \multicolumn{1}{c}{ Species } & California $^{1}$ & SW Peru & NW Chile & C Chile $^{{ }^{2}}$ \\
\hline Haematopus palliatus & 0 & 0.4 & 5 & 3.5 \\
H. ater & 0 & 0.5 & 0.2 & 0 \\
Pluvialis squatarola & 2.9 & 7.5 & 0.1 & 0 \\
Charadrius alexandrinus & 3.9 & 0.6 & 0.5 & 1.6 \\
Numenius phaeopus & 0.2 & 2.7 & 0.5 & 5.6 \\
Limosa fedoa & 3.2 & 0 & 0 & 0 \\
Arenaria interpres & 0.1 & 6.7 & 0 & 0 \\
A. melanocephala & 1.3 & 0 & 0 & 0 \\
Catoptrophorus semipalmatus & 4.5 & 0 & 0.1 & 0 \\
Calidris alba & 51 & 159 & 109 & 53 \\
Larus modestus & 0 & 220 & 110 & 29 \\
\multicolumn{1}{c}{ Total } & 67 & 397 & 225 & 93 \\
\hline
\end{tabular}

'Average density in 12 censuses of $1.5 \mathrm{~km}$ of sandy beach at Bodega Bay; sampled Decembers, 1978-1980.

${ }^{2}$ Average density on 8 samples of sandy beach totaling 36 censused km between Lima and Mollendo; March 1982.

3 Average density on 6 samples of sandy beach near Hornitos totaling 31 censused km; December 1982.

4 Average density on 2 samples of sandy beach near Rio Huasco totaling 11.4 censused km; December 1982.

, Birds $/ \mathrm{km}$.

The competition factor does not require any underlying geographic variation in the baseline abundance of food independent of bird density. Interspecifically there are no clear patterns in this case. The number of species of sympatrically wintering Nearctic shorebirds declines sharply south of the equator in the western hemisphere (Pitelka 1979), but within sandy beach habitats if there is any change, it is the opposite of that predicted (Table 2). Of those we considered (Table 2), several are known to share prey species with Sanderlings, particularly the Willet (Catoptrophorus semipalmatus), the Whimbrel (Numenius phaeopus), and the Grey Gull (Larus modestus) Reeder 1951; Koepke and Koepke 1952; Connors et al. 1981; Myers, unpubl. data. These three species and Sanderlings prey heavily upon the sandcrab Emerita analoga when feeding on open coast sandy beaches. The northern hemisphere has no form comparable to the Grey Gull, an abundant species along the Humboldt Current coast and a sandcrab specialist.

These comparisons tell us little, however, about competition per se. Not only are the data sparse, but more importantly, we lack baseline information on the availability of food and on the effect of bird density on foraging success at locally prevailing food abundances. In the northern hemisphere data now point toward strong competitive interactions: shorebirds deplete their prey through the winter (Evans et al. 1979; Goss-Custard 1980; Quammen 1980; Myers et al., unpubl. data). Duffy et al. (1981) have argued that shorebirds in Peru do not compete for food, but their results are empirically weak (Myers and McCaffery 1984). Puttick (1980) suggests that Curlew Sandpipers (C. ferruginea) in South Africa have superabundant resources. If these suggestions can be confirmed and generalized, then a good case may be built for reduced competition being a benefit for long-distance migrants. Densities of sympatric wintering shorebirds (Table 2) indicate, however, that a reduction in competition is not due simply to patterns in bird distribution; some geographic difference in resource abundance must be involved. In other words, reduction in competition may be a necessary factor, but it is not a sufficient one.

\section{CONCLUSIONS}

Sanderling nonbreeding distribution in the New World is not the homogeneous pattern one might expect from range maps or from casual excursions along a few sandy beaches. Sanderlings occur in most suitable habitat within their extraordinarily broad range, but in only a few regions do they become abundant. These areas of concentration lie along the Pacific Coast, especially in southwest Peru and northern Chile. Elsewhere, their apparent commonness may be more a result of the ease with which they can be detected in their habitat, than of numerical abundance. 
We cannot yet resolve the demographic and ecological bases underlying this distribution, nor those of the long-distance migration it requires. Resource conditions for Sanderlings appear to be more favorable on Chile's northern coast than in California. The data remain sketchy, however, and demand amplification with detailed ecological and demographic comparisons at these sites, near the northern and southern ends of Sanderlings' winter distribution.

\section{ACKNOWLEDGMENTS}

F. A. Pitelka inspired this work, and his influence runs (wild) throughout. Grants to him from the National Science Foundation funded much of the basic work at Bodega Bay. South American field work was supported by The World Wildlife Fund-US and the International Council for Bird Preservation-Panamerican Section. We thank R. Lee and P.-J. Subaru for the use of a field vehicle. Volunteers in the Sanderlings Project, led by coordinators C. Hohenberger and T. Schick, obtained much of the census data along the United States Pacific Coast. A. Amos, R. I. G. Morrison and J. R. Walters provided unpublished censuses. The Bodega Marine Laboratory, particularly P. Siri, greatly facilitated our field efforts. L. Myers contributed editorial skills and tolerance, and F. Gill gave at least the former. M. S. Foster clarified our writing style. R. Ricklefs gave his and his computer's time generously. In the field we have been helped by B. McCaffery, M. Cikutovits, P. G. Connors, R. Culver, K. Havelock, E. Hernandez, C. Maizels, E. Ortiz, V. Pulido, J. Walters and S. Williams.

\section{LITERATURE CITED}

Alerstrom, T., AND P. H. ENCKell. 1979. Unpredictable habitats and the evolution of bird migration. Oikos 33:228-232.

BAKER, R. R. 1978. The Evolutionary Ecology of Animal Migration. Holmes and Meier, New York. BENT, A. C. 1927. Life histories of North American shorebirds. Pt. I. U.S. Nat. Mus. Bull. 142.

BLEM, C. R. 1981. Geographic variation in mid-winter body composition of starlings. Condor 83:370376.

BLONDEL, J. 1969. Les migrations transcontinentales d'oiseaux vues sous l'angle ecologique. Bull. Soc. Zool. Fr. 94:577-598.

BOYD, H. 1962. Mortality and fertility of European charadrii. Ibis 104:368-387.

BRANSON, M. J. B. A. (ED.). 1979. Wash Wader Ringing Group. Report 1977-1978. Cambridge, England.

ChAPMAN, B. R. 1984. Seasonal abundance and habitat use patterns of coastal bird populations on Padre and Mustang Island barrier beaches. U.S. Fish Wildl. Serv. Div. Biol. Serv., Washington, D.C. FWS/BS-84/02.

CRAMP, S. (SR. ED.). 1983. Handbook of the birds of Europe the Middle East and North Africa. Vol. III. Waders to Gulls. Oxford University Press, Oxford, England.

COHEN, D. 1967. Optimization of seasonal migratory behavior. Am. Nat. 101:5-18.

Connors, P. G., J. P. MYers, C. S. W. ConNorS, AND F. A. PitelKA. 1981. Interhabitat movements by Sanderlings in relation to foraging profitability and the tidal cycle. Auk 98:49-64.

Cox, G. W. 1968. The role of competition in the evolution of migration. Evolution 22:180-192.

Davidson, N. C. 1981a. Survival of shorebirds (Charadrii) during severe weather: the role of nutritional reserves. Marine Science 15:231-240.

Davidson, N. C. 1981 b. Seasonal changes in nutritional condition of shorebirds (Charadrii) during the non-breeding season. Unpubl. Ph.D. dissert., University of Durham, Durham, England.

Davidson, N. C. 1982. Changes in the body-condition of redshanks during mild winters: an inability to regulate reserves? Ringing Migr. 4:51-62.

Dingle, H. 1980. Ecology and evolution of migration. Pp. 1-101, In S. A. Gauthreaux (ed.), Animal Migration, Orientation, and Navigation. Academic Press, New York.

Drent, R. H., AND S. DAAN. 1980. The prudent parent: energetic adjustments in avian breeding. Ardea 68:225-252.

DufFy, D. C., N. AtKins, AND D. C. SChNeIDER. 1981. Do shorebirds compete on their wintering grounds? Auk 98:215-229.

Dugan, P. J., P. R. Evans, L. R. Goodyear, and N. C. Davidson. 1981. Winter fat reserves in shorebirds: disturbance of regulated levels by severe weather conditions. Ibis 123:359-363.

DunNe, P., D. Sibley, C. Sutton, AND W. WANDER. 1982. Aerial surveys in Delaware Bay: confirming an enormous spring staging area for shorebirds. Wader Study Group Bull. 35:32-33.

EisenmanN, E. 1951. Northern birds summering in Panama. Wilson Bull. 63:181-185.

Elliot, C. C. H., M. Waltner, L. G. Underhill, J. S. Pringle, And W. J. A. Dick. 1976. The migration system of the Curlew Sandpiper Calidris ferruginea in Africa. Ostrich 47:191-213.

Evans, P. R., D. M. Herdson, P. J. Knights, And M. W. Pienkowski. 1979. Short term effects of reclamation of part of Seal Sands, Teesmouth, on wintering waders and Shelduck. I. Shorebird 
diets, invertebrate densities and the impact of predation on the invertebrates. Oecologia 41:183206.

Evans, P. R., AND P. C. Smith. 1975. Studies of shorebirds at Lindisfarne, Northumberland, 2. Fat and pectoral muscle as indicators of body condition in the Bar-tailed Godwit. Wildfowl 26:64-76.

FreTWELL, S. D. 1969. Dominance behavior and winter habitat distribution in junco (Junco hyemalis). Bird-Banding 39:293-306.

FRETWELL, S. D. 1980 . Evolution of migration in relation to factors regulating bird numbers. Pp. 493504, In A. Keast and E. S. Morton (eds.), Migrant Birds in the Neotropics. Smithsonian Institution Press, Washington, D.C.

Gauthreaux, S. A. 1978. The ecological significance of behavioral dominance. Pp. 17-54, In P. P. G. Bateson and P. H. Klopfer (eds.), Perspectives in Ethology. Plenum, New York.

Gauthreaux, S. A. 1982. The ecology and evolution of avian migration systems. Pp. 93-168, In D. S. Farner, J. R. King, and K. C. Parkes (eds.), Avian Biology, Vol. 6. Academic Press, New York. Glutz Von Blotzheim, U. N., K. M. BAueR, AND E. Bezzel. 1975. Handbuch der Vogel Mitteleuropas 6.

Godfrey, W. E. 1966. The birds of Canada. Natl. Mus. Canada Bull. No. 203, Biol. Ser. No. 73.

Goss-CuSTARD, J. D. 1980. Competition for food and interference among waders. Ardea 68:31-52.

Goss-Custard, J. D., R. E. Jones, AND L. HARRISON. 1981. Weights of Knot in captivity. Wader Study Group Bull. 32:34-35.

Greenberg, R. S. 1980. Demographic aspects of long-distance migration. Pp. 493-504, In A. Keast and E. S. Morton (eds.), Migrant Birds in the Neotropics. Smithsonian Institution Press, Washington, D.C.

HAARTMANN, L. vON. 1968. The evolution of resident versus migratory habit in birds. Some considerations. Ornis Fenn. 45:1-7.

Herrera, C. M. 1978. On the breeding distribution pattern of European migrant birds: MacArthur's theme reexamined. Auk 95:496-509.

ISLEIB, P. 1979. Migratory shorebird populations on the Copper River Delta and Eastern Prince William Sound, Alaska. Stud. Avian Biol. 2:125-130.

Johnson, O. W. 1979. Biology of shorebirds summering on Enewetak Atoll. Stud. Avian Biol. 2:193205.

Johnson, O. W., AND P. W. Johnson. 1983. Plumage-molt-age relationships in "over-summering" and migratory Lesser Golden-Plovers. Condor 85:406-419.

Kendeigh, S. C., V. R. Dol'nik, And V. M. Gavrilov. 1977. Avian energetics. Pp. 129-204, In J. Pinowski and S. C. Kendeigh (eds.), Inter. Biol. Prog. 12: Granivorous birds in ecosystems.

Ketterson, E. D., AND V. Nolan, JR. 1982. The role of migration and winter mortality in the life history of a temperate-zone migrant, the dark-eyed junco, as determined from demographic analyses of winter populations. Auk 99:243-259.

Ketterson, E. D., AND V. Nolan, JR. 1983. A review of hypotheses to account for the evolution of differential bird migration, with particular reference to the dark-eyed junco (Junco h. hyemalis). Current Ornithol. 1:357-402.

Klopfer, P. H., D. I. Rubenstein, R. S. Ridgely, and R. J. Barnett. 1974. Migration and species diversity in the tropics. Proc. Natl. Acad. Sci. USA 71:339-340.

KOEPKE, H. W., AND M. KOEPKE. 1952. Sobre el proceso de transformación de la matéria organica en las playas arenosas marinas del Peru. Publ. Mus. Hist. Nat. Javier Prado, Peru. Ser. A. Zool. 8:125.

LACK, D. 1954. The Natural Regulation of Animal Numbers. Oxford University Press, London.

LACK, D. 1968. Bird migration and natural selection. Oikos 19:1-9.

MACARTHUR, R. H. 1959. On the breeding distribution patterns of North American migrant birds. Auk 76:318-325.

MCNeIL, R., AND F. CADIEAux. 1972. Fat content and flight range capabilities of some adult spring and fall migrant North American shorebirds in relation to migration routes on the Atlantic Coast. Nat. Can. 99:589-606.

Morrison, R. I. G. 1984. Migration patterns of shorebirds in the New World. In press, In J. Burger and O. Bolla (eds.), The behavior of Marine Organisms, Vol. 6.

MYERS, J. P. 1980a. Sanderlings Calidris alba at Bodega Bay: facts, inferences and shameless speculations. Wader Study Group Bull. 30:26-32.

MYERS, J. P. 1980b. The Pampas shorebird community: interactions between breeding and nonbreeding members. Pp. 37-49, In A. Keast and E. S. Morton (eds.), Migrant Birds in the Neotropics. Smithsonian Institution Press, Washington, D.C.

MYERS, J. P. 1981a. A test of three hypotheses for latitudinal segregation of the sexes in wintering birds. Can. J. Zool. 59:1527-1534.

MYERS, J. P. 1981b. Cross-seasonal interactions in the evolution of sandpiper social organization. Behav. Ecol. Sociobiol. 8:195-202.

MYERS, J. P. 1984. Spacing behavior of nonbreeding shorebirds. Behav. Marine Organ. 6:273-323.

Myers, J. P., G. Castro, B. Harrington, M. Howe, J. Maron, E. Ortiz, M. Sallaberry, C. T. Schick, AND E. TABILO. 1984. The Pan American shorebird program: a progress report. Wader Study Group Bull. 42:26-31. 
Myers, J. P., P. G. Connors And F. A. Pitelka. 1981. Optimal territory size and the Sanderlings: compromises in a variable environment. Pp. 135-158, In A. C. Kamil and T. D. Sargent (eds.), Mechanisms of Foraging Behavior. Garland Press, New York.

Myers, J. P., AND B. J. MCCAFFery. 1984. Paracas revisited: do shorebirds compete on their wintering ground? Auk 101:197-199.

Myers, J. P., AND M. SAllaberRy. 1984. Como capturar y anillar Calidris alba. Volante Migratorio 2:30-37.

Myers, J. P., C. T. SChick, AND C. J. Hohenberger. 1984. Notes on the 1983 distribution of Sanderlings along the United States' Pacific Coast. Wader Study Group Bull. 40:22-26.

Myers, J. P., S. L. Williams, AND F. A. PitelKA. 1980. An experimental analysis of prey availability for Sanderlings Calidris alba Pallas feeding on sandy beach crustaceans. Can. J. Zool. 58:15641574.

NICE, M. M. 1937. Studies in the life history of the Song Sparrow. I. Trans. Linn. Soc. 4:1-247.

O'CONNOR, R. J. 1981. Comparison between migrant and non-migrant birds in Britain. Pp. 167-196, In D. J. Aidley (ed.), Animal Migration. Soc. Exper. Biol., Sem. Ser. 13.

PAGe, G., AND D. F. WhItACRE. 1975. Raptor predation on wintering shorebirds. Condor 77:73-83.

PitelKA, F. A. 1974. An avifaunal review for the Barrow region and north slope of arctic Alaska. Arct. Alp. Res. 6:161-184.

Pitelka, F. A. 1979. Introduction: the Pacific Coast shorebird scene. Stud. Avian Biol. 2:1-11.

Prater, A. J., J. H. Marchant, and J. Vuorinen. 1977. Guide to the identification and ageing of holarctic waders. British Trust for Ornithology Guide 17.

Putrick, G. M. 1980. Energy budgets of Curlew Sandpipers at Langebaan Lagoon, South Africa. Estuarine Coast. Mar. Sci. 11:207-215.

QuAmmen, M. L. 1980. The impact of predation by shorebirds, benthic feeding fish and a crab on shallow living invertebrates in intertidal mudflats of two southern California lagoons. Unpubl. Ph.D. dissert., University of California, Irvine.

ReEder, W. G. 1951. Stomach analysis of a group of shorebirds. Condor 53:43-45.

SAlomonsen, F. 1955. The evolutionary significance of bird migration. Danske Viden. Sels. Biolog. Medd. 22:1-62.

Schick, C. T. 1983. Weight loss in Sanderlings Calidris alba after capture. Wader Study Group Bull. 38:33-34.

SouthwOod, T. R. E. 1977. Habitat, the templet for ecological strategies? J. Anim. Ecol. 46:337-365.

SWARTH, H. S. 1920. Revision of the avian genus Paserella with special reference to the distribution and migration of the races in California. Univ. Calif. Publ. Zool. 21:75-224.

Willson, M. F. 1976. The breeding distribution of North American migrant birds: a critique of MacArthur (1959). Wilson Bull. 88:582-587.

Walters, J. R. 1984. Sanderlings in North Carolina. Wader Study Group Bull. 40:27-29. 